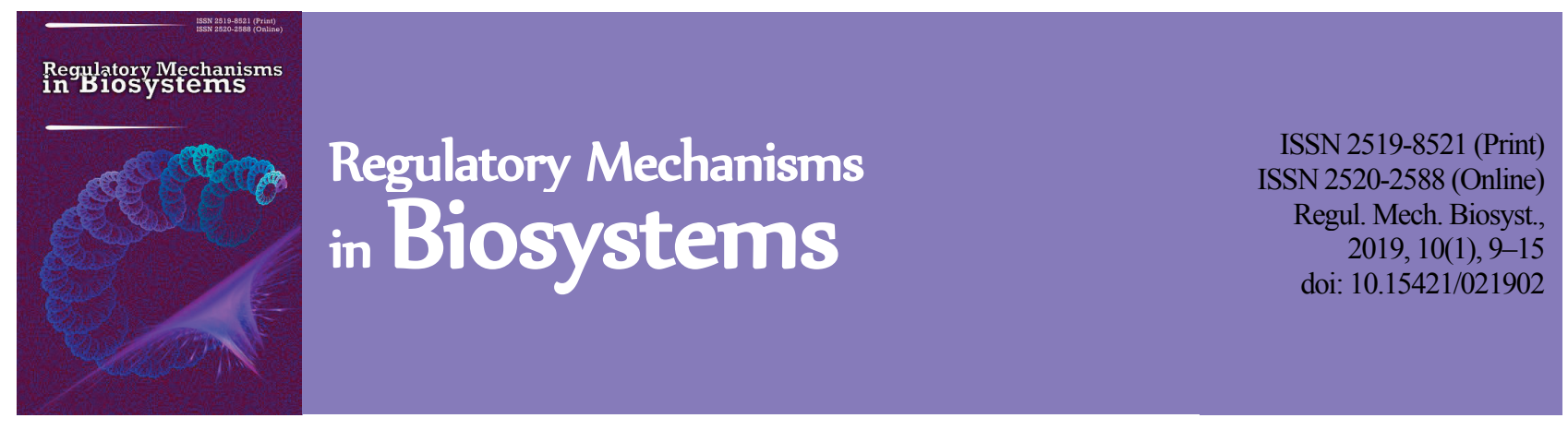

\title{
Morphological and physiological traits of the mesonephros in a freshwater fish, grayling Thymallus thymallus
}

\author{
E. A. Flerova*,**, A. A. Morozov***, A. A. Bogdanova**, \\ D. V. Chupov****, G. M. Ustiuzhinskii****, V. V. Yurchenko*** \\ *P. G. Demidov Yaroslavl State University, Yaroslavl, Russia \\ **Yaroslavl Scientific Research Institute of Livestock Breeding and Forage Production - Federal State Budget Sciences Institution \\ "Federal Williams Research Center of Forage Production and Agroecology", Mihajlovskij, Russia \\ ***Papanin Institute for Biology of Inland Waters of Russian Academy of Sciences, Borok, Russia \\ ****Polar Research Institute of Marine Fisheries and Oceanography, Murmansk, Russia
}

Article info

Received 15.01.2019

Received in revised form 20.02.2019

Accepted 25.02.2019

P. G. Demidov Yaroslavl State University Sovetskava Street, 14, Yaroslavl, 150003 Russia. Tel.: 48-52-797-702. E-mail:katarinum@mail.ru

Federal Williams Research Center of Forage Production and Agroecology Lenin st., 1, Mihajlovskij, 157517, Yaroslavskaja Oblast, Russia. Tel.: 48-52-437-567. E-mail: aleksey.a.morozov@gmail.com

Papanin Institute for Biology of Inland Waters of Russian Academy of Sciences Nekouz, 109, Borok, 152742, Yaroslavskaja Oblast, Russia. Tel.: 48-54-724-816.

Polar Research Institute of Marine Fisheries and Oceanography Knipovitch st., 6, Murmansk, 183038 Russia. Tel.: 8152-402-600-10-38

\section{Introduction}

In the course of evolution, a general mechanism of non-specific protection was developed. Immune, antioxidant, and monooxygenase systems are the most important components of this protection. These systems provide the interaction between an organism and its environment. From a comparative-evolutionary perspective, it is very important to study the structural and functional features of the mesonephros, which not only plays the main role in the osmotic regulation, but also contributes significantly to homeostasis at the level of the non-specific protection. In this regard, studies on the salmonids, a unique family of anadromous and freshwater fishes having some relatively primitive morphological traits, are of current importance.

There are a number of studies on various aspects of mesonephros morphology and physiology of anadromous salmonids in relation to the smoltification process (Langdon, 1985; Talbot et al., 1992; Boeuf, 1993; Mizuno et al., 2001; Björnsson \& Bradley, 2007), while studies on morphological and physiological traits of the mesonephros in freshwater salmonids are few in number (Anderson \& Loewen, 1975; Kocabatmaz
Flerova, E. A., Morozov, A. A., Bogdanova, A. A., Chupov, D. V., Ustiuzhinskii, G. M., \& Yurchenko, V. V. (2019). Morphological and physiological traits of the mesonephros in a freshwater fish, grayling Thymallus thymallus.

The study presents new data on the structural and functional organization of the mesonephros of the grayling Thymallus chloride cells were discovered; the latter were mostly localized near the renal tubules. The degree of the interstice in the mesonephros of the grayling was determined. New data on the ultrastructure of leukocytes, cells with a observed on the sections of a renal corpuscle, being characteristic features of the ultrathin organization of the mesonephros in freshwater members of Salmoniformes and Esociformes. In the the processes, with large numbers of invaginations of cytoplasmic membrane, were found. On the basis of the distinctive euryhalinity features mentioned above, the inference that grayling show the cytological markers of adaptation to . From the species protection standpoint, our study provides baseline data on a WBC differential in the mesonephros well as superoxide dismutase, catalase, glutathione S-transferase, and ethoxyresorufin-O-deethylase activities, which can

Keywords: microanatomy; ultrastructure; leukocytes; antioxidants; ethoxyresorufin-O-deethylase; kidney.

\& Ekingen, 1987; Katoh et al., 2008). The grayling, Thymallus thymallus (Linnaeus, 1758) is a freshwater salmonid species. The grayling is a benthopelagic fish, which feeds on chironomid and simuliid larvae, drifting macroinvertebrates, ephemeropteran nymphs, fish larvae (Scott, 1985). It inhabits submontane reaches of rivers with a hard sand or stone bottom and well oxygenated, cold and fast-flowing water (Freyhof, 2011). The grayling is listed in the IUCN Red List with the Least Concern (LC) status. Grayling populations are threatened by overfishing as well as by natural system modifications, such as dam construction and water management, and habitat pollution with domestic and urban wastewaters, industrial, military, agricultural, and forestry effluents (Nykänen et al., 2001; Freyhof, 2011).

The purpose of our study was to perform an integrated research on structural and functional organization of the mesonephros of grayling. The data obtained in this study are a valuable contribution to the comparative-evolutionary conception of the mesonephros ultrastructure in lower vertebrates. From a practical perspective, our results can be used in the aquatic biomonitoring as well as ichthyopathological assessment procedures in grayling culture. 


\section{Materials and methods}

The fish sampling performed within the study was conducted by the Fresh Water Fishes Laboratory (SevPINRO) in July 2012. Grayling was sampled in the middle course of the Unya River, a tributary of the Pechora River (Fig. 1). The Unya River flows 163 kilometers and has a total catchment area of 2,890 square kilometers. The Unya River has a rocky stream bed, with rifts and rapids. By chemical composition, the river waters belong to the hydrocarbonate class; total dissolved solids concentrations vary from 200 to $500 \mathrm{mg} /$. Fish sampling was carried out in the "Unyinskiy" protected area, which is located in a buffer zone of the Pechora-Ilych Nature Reserve. Due to its remoteness and inaccessibility, the area does not experience any significant anthropogenic impact, and thus, the area was considered suitable for the baseline study of morphological and physiological traits of the mesonephros in grayling.

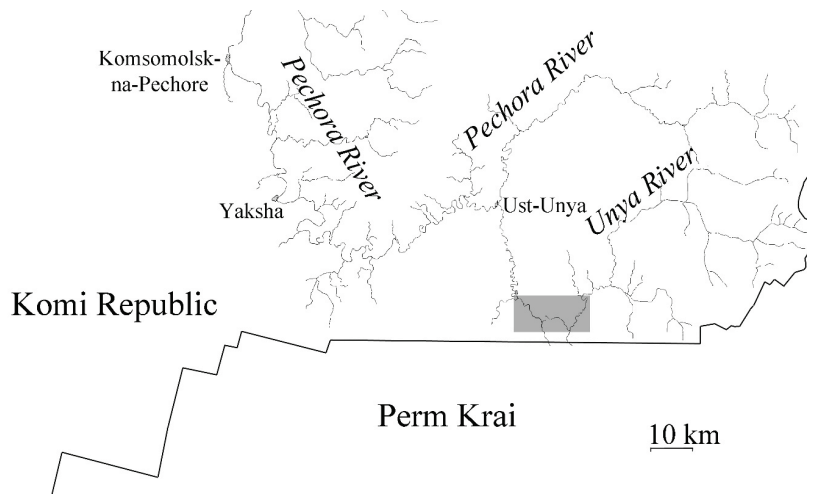

Fig. 1. Sampling site (marked with a grey rectangle)

Fish were collected using a minnow seine, $20 \mathrm{~m}$ long, with a $3 \mathrm{~mm}$ mesh in a bag. Ten sexually mature fish were used for the study. Each specimen was immobilized by a blow to the head, measured and weighed (Table 1). Then it was dissected, eviscerated and weighed, the maturity stage was determined visually, on a 5-point scale, and the mesonephros samples were taken.

Table 1

Body measurements, sex and maturity stage of the grayling from the Unya River

\begin{tabular}{|c|c|c|c|c|c|c|}
\hline Specimen & $\mathrm{TL}, \mathrm{cm}$ & $\mathrm{FL}, \mathrm{cm}$ & $\mathrm{SL}, \mathrm{cm}$ & TW,g & EW, g & Sex* \\
\hline 1 & 29.2 & 27.0 & 25.9 & 205 & 179 & 93 \\
\hline 2 & 27.7 & 26.5 & 25.0 & 192 & 172 & 3 \\
\hline 3 & 27.6 & 25.4 & 24.1 & 174 & 154 & 32 \\
\hline 4 & 27.0 & 25.3 & 24.0 & 175 & 154 & ㅇ 3 \\
\hline 5 & 25.5 & 23.6 & 22.5 & 130 & 115 & +3 \\
\hline 6 & 23.9 & 22.3 & 21.0 & 126 & 106 & 2 \\
\hline 7 & 23.5 & 22.1 & 20.9 & 113 & 98 & 32 \\
\hline 8 & 23.4 & 22.0 & 20.7 & 100 & 85 & +2 \\
\hline 9 & 22.7 & 21.0 & 19.8 & 80 & 63 & +3 \\
\hline 10 & 20.2 & 18.3 & 17.3 & 63 & 54 & 2 \\
\hline
\end{tabular}

Note: TL - total length, FL - fork length, SL - standard length, TW - total weight, EW - eviscerated weight, ${ }^{*}$ - sex and maturity stage.

Mesonephros samples intended for biochemical assays were immediately frozen in liquid nitrogen and stored in it until the analytical procedure. Organ smears were made on slides, allowed to dry for $10 \mathrm{~min}$ and set in a container with $96 \%$ ethanol for $20 \mathrm{~min}$. Samples intended for microanatomy and ultrastructure analyses were fixed in $2.5 \%$ glutaraldehyde solution prepared with $0.1 \mathrm{M}$ phosphate buffer, postfixed in $1 \%$ osmium tetroxide for $1 \mathrm{hr}$, dehydrated in graded acetone and propylene oxide, and embedded in Araldite (Electron Microscopy Sciences, USA) (Timakova et al., 2014).

Superoxide dismutase, catalase, and glutathione S-transferase activities were analyzed according to conventional spectrophotometric protocols described earlier (Morozov \& Yurchenko, 2018) using a Perkin Elmer Lambda 25 spectrometer (UK). Ethoxyresorufin-O-deethylase activity was measured fluorometrically (described previously in Yurchenko \& Morozov, 2018) using a Perkin Elmer LS 55 spectrometer (UK).
Microanatomical study of the mesonephros was carried out according to the standard methods. Semi-thin sections $(2-3 \mu \mathrm{m})$ were cut with a UMTP-3 microtome (Russia). Dry sections were stained with methylene blue. Using a Micromed-6 light microscope (Russia), digital photographs were taken, which were then processed with Image Tool 3.0 software. The outer diameter (OD) of blood vessels, renal corpuscles and tubules were measured. The area of hematopoietic tissue was calculated as the difference between the total area of a section and the sum of the areas of blood vessels, renal corpuscles and tubules (Timakova et al., 2014).

Ultra-thin sections were cut using a Leica EM UC7 Ultracut (Germany). Sections were stained with uranyl acetate and lead citrate and analyzed using a JEM 1011 transmission electron microscope (Japan). Measurements were carried out on digital pictures.

A white blood cell (WBC) differential was studied on the Romanowsky-Giemsa-stained organ-smears using a Micromed-6 light microscope (Russia). A WBC differential analysis was performed on at least 200 cells at each organ-smear (Timakova et al., 2014). Data were reported as the mean \pm standard error of the mean $(\mathrm{x} \pm \mathrm{SE})$.

\section{Results}

Biochemical analyses. Enzyme activities in the mesonephros of grayling were as follows: ethoxyresorufin-O-deethylase $-0.22 \pm 0.05$ $\mathrm{pmol} / \mathrm{mg} / \mathrm{min}$, superoxide dismutase $-1.08 \pm 0.27$, catalase $-1.23 \pm$ 0.21 , and glutathione S-transferase $-0.91 \pm 0.19 \mu \mathrm{mol} / \mathrm{mg} / \mathrm{min}$.

Mesonephros microanatomy. In the mesonephros of grayling, the area of hematopoietic tissue was $46.9 \pm 2.7 \%$ of the total area of the sections. The average OD of the blood vessels was $36.13 \pm 2.28 \mu \mathrm{m}$ (Fig. 2). In the mesonephros interstitial tissue, erythrocytes and leucocytes were distinguishable at the light-microscopy level (Fig. 2). Among the mature leucocytes, the lymphocytes were the most abundant and comprised $74.4 \pm 2.8 \%$. The second largest group $(10.8 \pm 2.3 \%)$ was represented by multipotential hematopoietic stem cells, hemocytoblasts. Granulocyte progenitors varied from 3 to $4 \%$ (promyelocytes $4.1 \pm$ $0.8 \%$, myelocytes $3.0 \pm 0.9 \%$, metamyelocytes $2.9 \pm 0.9 \%$ ). The amount of granulocytes decreased in the following order: banded neutrophils $2.5 \pm 0.4 \%$, segmented neutrophils $1.0 \pm 0.5 \%$, macrophages $0.90 \pm 0.29 \%$, and plasma cells $0.50 \pm 0.10 \%$.

The nephron segments were well distinguishable on the sections. The Bowman's capsule was composed of epithelium, surrounded by an intensely stained basement membrane. A tuft of capillaries, the glomerulus, enclosed in the sac was distinguishable. These segments together, known as a renal corpuscle, had a size of $62.44 \pm 3.82 \mu \mathrm{m}$. On the cross-sections of the proximal tubule, with an OD of $53.07 \pm 1.77 \mu \mathrm{m}$, a brush border was distinguishable. The proximal tubule was composed of epithelial cells, enclosed by an intensely stained basement membrane. Each epithelial cell had an intensely stained oval or rounded nucleus, which in most cells, was located at the basal side. The distal tubule (OD $56.71 \pm 2.59 \mu \mathrm{m}$ ) was also composed by epithelial cells, enclosed by the basement membrane; intensely stained oval or rounded nuclei were located at the central part of the cells. On the cross-sections of the distal tubule, a brush border was not present.

Mesonephros ultrastructure. Mesonephros interstitial tissue contained the following types of leukocytes: lymphocytes, plasma cells, macrophages, neutrophils, eosinophils, cells with a radial vesicle array, and chloride cells. A characteristic feature of grayling's lymphocytes was a large rounded nucleus, which occupied almost the entire cell volume. Heterochromatin was evenly localized to the periphery of the nucleus. The thin rim of the electron-light cytoplasm contained free ribosomes and two mitochondria on average (Table 2, Fig. 3b).

Plasma cells, mostly oval-shaped, contained a rounded nucleus located in the center of the cell. In most cells, heterochromatin was segmented, evenly localized to the periphery of the nucleus. The cytoplasm contained stacks of a well-developed rough endoplasmic reticulum, $0.68 \pm 0.06 \mu \mathrm{m}$ wide, free ribosomes, one mitochondrion on average, and the electron-dense lysosomes (Table 2, Fig. 2c).

Macrophages are the largest leukocyte cells. The nuclei were eccentrically shifted; heterochromatin was evenly localized to the periphe- 
ry of the nucleus. The cytoplasm contained electron-dense phagosomes of various sizes (Table 2 ), which occupied almost the entire cell volume. The cytoplasm also contained mitochondria, short double membrane sheets of the rough endoplasmic reticulum, free ribosomes, lysosomes, and small light vesicles (Table 2, Fig. 2d). In some cells, a large number of the electron-dense pigment granules were found.
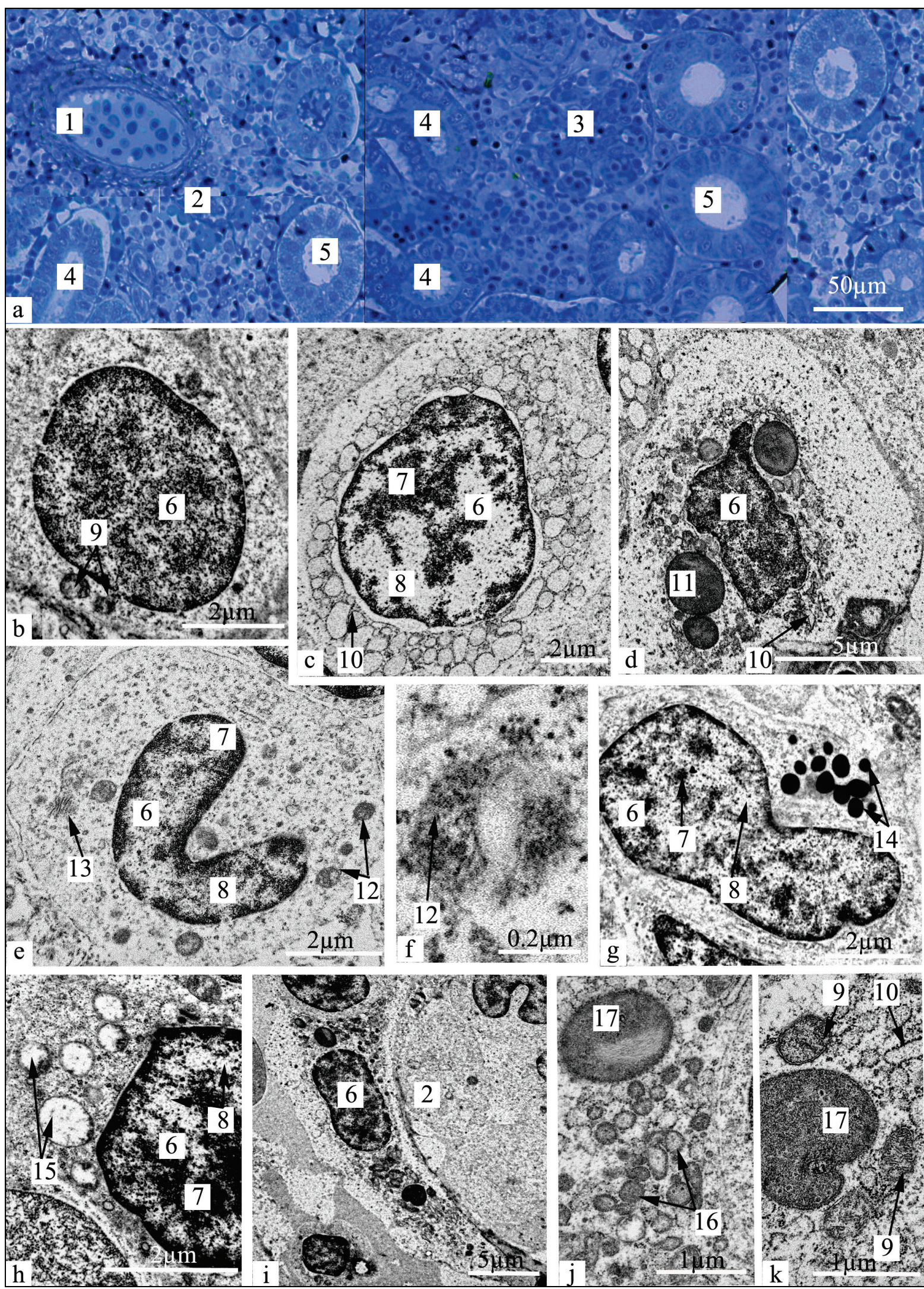

Fig. 2. Microanatomy of the mesonephros of grayling, Thymallus thymallus: $a$-mesonephros tissues; $b$-lymphocyte; $c$ - plasma cell;

$d$-macrophage; $e$-neutrophil; $f$-intra-cellular granule of a neutrophil; $g$ - eosinophil; $h$-cell with a radial vesicle array; $i$-chloride cell; $j, k$-cytoplasm of a chloride cell; 1 - blood vessel; 2 -hematopoietic tissue; 3 - renal corpuscle; 4 - proximal tubule; 5 -distal tubule; 6 -nucleus; 7-heterochromatin; 8-euchromatin; 9-mitochondrion; 10 -rough endoplasmic reticulum; 11 - phagosome; 12 - intra-cellular granule of a neutrophil; 13 -Golgi apparatus; 14 - intra-cellular granules of an eosinophil; 15 -radial vesicle array; 16 -tubular reticulum; 17-secondary lysosome 

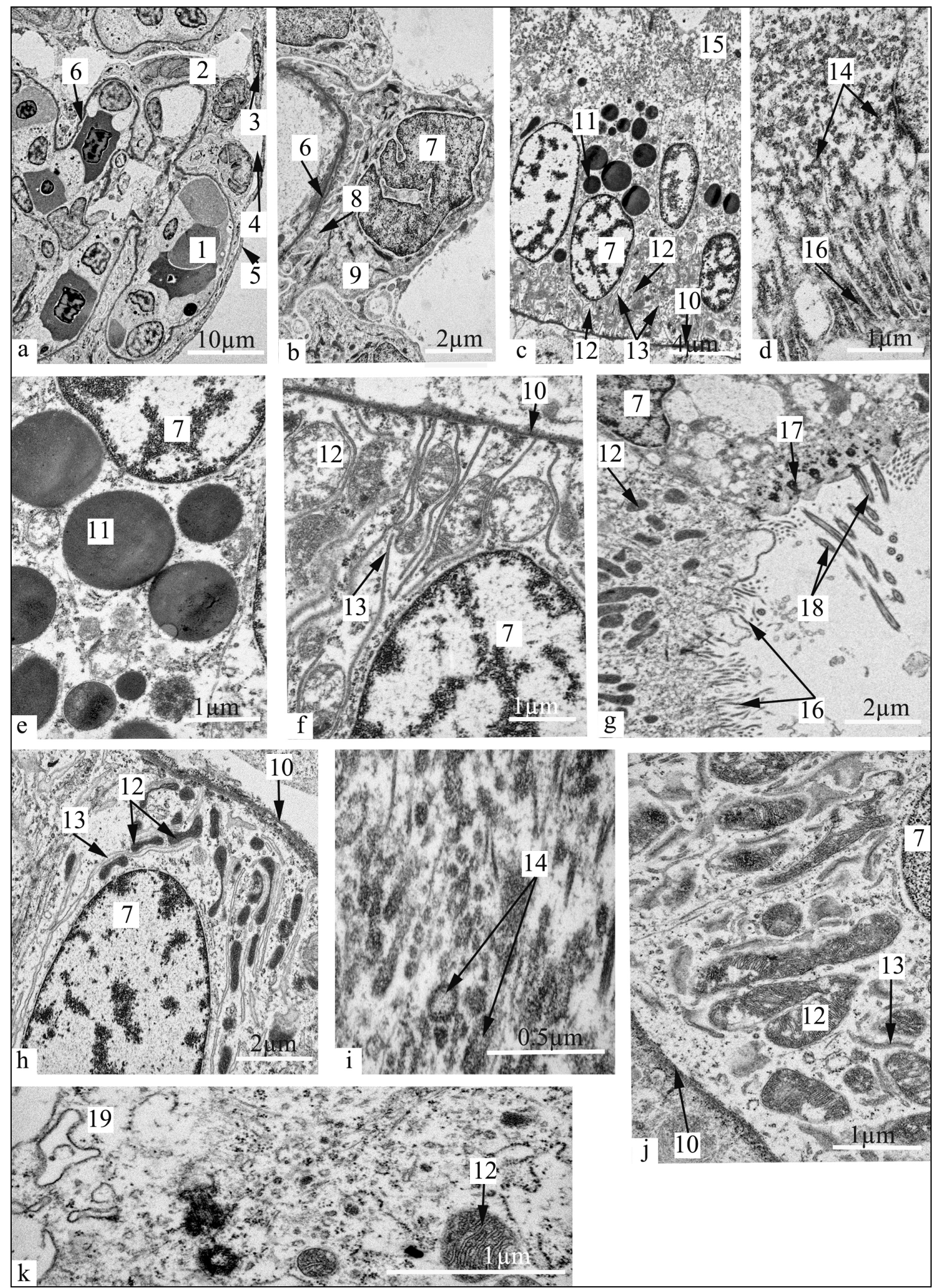

Fig. 3. Ultrastructure of nephron in mesonephros of grayling, Thymallus thymallus: $a$-renal corpuscle; $b$ - podocyte; $c$-section of the proximal tubule;

$d$-brush border; $e$-cytoplasm of the type I epithelial cell of the proximal tubule; $f$-basal part of the type I epithelial cell of the proximal tubule; $g$ - section of the proximal tubule with a ciliated cell; $h$-basal part of the type II epithelial cell of the proximal tubule; $i$-zone of endocytosis; $j$-basal part of the distal tubule; $k$-apical part of the distal tubule; 1 - glomerular capillary; 2 - podocyte; 3 - epithelial cell of the parietal layer of the Bowman's capsule; 4 -Bowman's space; 5 - basement membrane of the parietal layer; 6 -basement membrane of the visceral layer; 7 -nucleus; 8 -pedicels of a podocyte; 9 - podocyte; 10 - tubular basement membrane; 11 - secretory granules; 12 - mitochondrion; 13 - smooth endoplasmic reticulum; 14-tubularvesicular network; 15 - brush border; 16-brush border microvilli; 17 - basal body of a cilium; 18-cilium; 19-blade-shaped cytoplasmic processes 
Table 2

Dimensions $(\mu \mathrm{m})$ and number of leukocyte subcellular structures in mesonephros of grayling, Thymallus thymallus $(\mathrm{x} \pm \mathrm{SE}, \mathrm{n}=20)$

\begin{tabular}{lccccc}
\hline \multicolumn{1}{c}{ Parameter } & Lymphocytes & Plasma cells & Macrophages & Neutrophils & Eosinophils \\
\hline Cell size & $6.17 \pm 0.36 \times 5.09 \pm 0.41$ & $11.07 \pm 1.04 \times 7.47 \pm 0.93$ & $15.35 \pm 1.28 \times 10.46 \pm 0.389 .18 \pm 0.65 \times 7.07 \pm 0.43$ & $9.92 \pm 1.01 \times 6.63 \pm 0.45$ \\
Nucleus size & $5.10 \pm 0.23 \times 4.36 \pm 0.33$ & $5.54 \pm 1.34 \times 4.49 \pm 0.63$ & $4.72 \pm 0.40 \times 3.75 \pm 0.53$ & $4.33 \pm 0.52 \times 2.77 \pm 0.35$ & $5.68 \pm 1.85 \times 3.42 \pm 0.59$ \\
Mitochondrion size & $0.53 \pm 0.11 \times 0.31 \pm 0.05$ & $0.42 \pm 0.06 \times 0.20 \pm 0.02$ & - & - & - \\
Number of mitochondria on a cell section & $2.00 \pm 0.71$ & $1.00 \pm 0.82$ & - & - & - \\
Large phagosome size & - & - & $2.57 \pm 0.39 \times 2.14 \pm 0.36$ & - & - \\
Number of large phagosomes on a cell section & - & - & $3.83 \pm 0.87$ & - & - \\
Small phagosome size & - & - & $0.30 \pm 0.01 \times 0.22 \pm 0.02$ & - & - \\
Number of small phagosomes on a cell section & - & - & $23.40 \pm 4.92$ & - & $0.39 \pm 0.02 \times 0.23 \pm 0.020 .44 \pm 0.03 \times 0.36 \pm 0.02$ \\
Size of specific granules, type I & - & - & - & $0.49 \pm 0.04 \times 0.41 \pm 0.02$ & - \\
Size of specific granules, type II & - & - & - & $6.25 \pm 1.66$ & $11.67 \pm 1.08$ \\
Number of granules on a cell section & - & & & -
\end{tabular}

Neutrophils were rounded (Fig. 2e). The shape of a nucleus varied from bean-like to segmental. Heterochromatin was segmented, localized mostly along the nucleus membrane. The cytoplasm contained mitochondria, the double membrane sheets of the rough and smooth endoplasmic reticula; in single cells, the Golgi apparatus was identified. Characteristic feature of neutrophils are specific intra-cellular granules that fill the cytoplasm. In the grayling's mesonephros, these granules had thin electron-dense stripes, fibrils, located along the granules. Two types of granules were found. The first type had fibrils located evenly along the granules. The second type had a lighter central part and dark fibrillar edges (Table 2, Fig. 2f).

Eosinophils also have specific granules that fill the cytoplasm. In the grayling's mesonephros, eosinophils had rounded electron-dense granules with a homogenous structure (Table 2, Fig. 2g).

Cells with a radial vesicle array are the rounded cells similar in size to lymphocytes (Table 3 ). These cells had eccentrically shifted nuclei. The nucleus was rounded, with a large amount of segmented heterochromatin. The cytoplasm was acinose; contained short stacks of the smooth endoplasmic reticulum and one mitochondrion. In the apical part of the cells, from three to six electron-transparent vesicles were observed (Fig. 2h).

Chloride cells were diffused throughout the parenchyma, and also surrounded renal tubules and blood vessels. The rounded nucleus was located closer to the periphery of the cell, heterochromatin was segmented. The cytoplasm was electron-light with a large amount of mitochondria. On the cell sections, single-membrane organelles were observed and identified as the secondary lysosomes. Also, large electrondense granules and two double-membrane organelles, tubular and rough endoplasmic reticula were distinguished. Single tubules were distributed throughout the cell. Stacks of the rough endoplasmic reticulum were mainly located in the perinuclear area and were few in number (Table 3 , Fig. 2i, 2j, 2k).

\section{Table 3}

Dimensions $(\mu \mathrm{m})$ and number of cells with a radial vesicle array, chloride cells, and their subcellular structures in the mesonephros of grayling, Thymallus thymallus $(\mathrm{x} \pm \mathrm{SE}, \mathrm{n}=20)$

\begin{tabular}{lcc}
\hline \multicolumn{1}{c}{ Parameter } & Cells with a radial vesicle array & Chloride cells \\
\hline Cell size & $5.27 \pm 0.67 \times 4.78 \pm 0.68$ & $17.67 \pm 3.16 \times 5.22 \pm 0.89$ \\
Nucleus size & $4.02 \pm 0.40 \times 3.44 \pm 0.15$ & $3.86 \pm 0.63 \times 3.72 \pm 0.61$ \\
Vesicle size & $0.69 \pm 0.08 \times 0.48 \pm 0.04$ & - \\
$\begin{array}{l}\text { Number of vesicles } \\
\text { on a cell section }\end{array}$ & $4.50 \pm 0.75$ & - \\
$\begin{array}{l}\text { Mitochondrion size } \\
\text { Number of mitochondria } \\
\text { on a cell section }\end{array}$ & - & $0.67 \pm 0.09 \times 0.54 \pm 0.15$ \\
\hline
\end{tabular}

Bowman's capsule has the parietal layer and visceral layer and the Bowman's space in between, into which the filtrate enters after passing through the filtration slits. In grayling, the Bowman's space was $3.81 \pm$ $0.78 \mu \mathrm{m}$ in size. The parietal layer was composed by a single layer of flat epithelial cells in contact with the basement membrane. Epithelial cells were elongated, with a centrally located nucleus. Heterochromatin was both located along the nuclear membrane and diffused in the nucleus. The cytoplasm contained mitochondria, reticulum sheets; sporadically vesicles were noted. The visceral layer was made of podocytes, $4.18-7.89 \mu \mathrm{m}$ in size. Podocytes were located on the outer side of the glomerulus capillaries. The nuclei of the podocytes had large invaginations, a well-developed rough endoplasmic reticulum, and from three to five mitochondria. The thickness of the glomerular basement membrane was $0.18 \pm 0.01 \mu \mathrm{m}$ (Fig. 3a, 3b).

Ultrastructure analysis of the proximal tubules in the nephrons of grayling showed two types of epithelial cells. The type I epithelial cells were located at the beginning of the proximal tubule; these were the largest cells in the proximal tubule. These epithelial cells had an elongated pyramidal shape, were tightly adjacent to each other, and had round-shaped nuclei located in the basal part of the cells. The cytoplasm was acinose and contained a large amount of mitochondria (Table 4, Fig. 3c). Basal cell membrane formed projections turning into the sheets of the smooth endoplasmic reticulum (Fig. 3f). These membrane projections were characteristic for all types of epithelial cells in all divisions of the tubule. Lysosomes and the large electron-dense secretory granules characteristic of this nephron segment were present (Table 4, Fig. 3e). In the apical part of the cells, adjacent to the brush border, there was a well-developed zone of endocytosis (Table 4, Fig. 3d). This zone was characterized by the presence of the tubulo-vesicular network (Fig. 3). The epithelial cells of this type had the longest microvilli. Furthermore, single cells, the brush border of which was formed by cilia, were found there (Table 4, Fig. 3g). Epithelial cells having cilia had a slightly different ultrastructure. The cytoplasm of these cells was less acinose; the apical edge of the cells was more electron-dense than that of epithelial cells having microvilli (Fig. 3g)

\section{Table 4}

Dimensions $(\mu \mathrm{m})$ and number of nephron subcellular structures in mesonephros of grayling, Thymallus thymallus $(\mathrm{x} \pm \mathrm{SE}, \mathrm{n}=20)$

\begin{tabular}{|c|c|c|c|c|}
\hline \multirow[b]{2}{*}{ Parameter } & \multirow[b]{2}{*}{$\begin{array}{l}\text { Bowman's } \\
\text { capsule } \\
\text { podocytes }\end{array}$} & \multicolumn{3}{|c|}{ Epithelial cells } \\
\hline & & $\begin{array}{l}\text { type I, } \\
\text { proximal } \\
\text { tubule }\end{array}$ & $\begin{array}{l}\text { type II, } \\
\text { proximal } \\
\text { tubule }\end{array}$ & $\begin{array}{c}\text { distal } \\
\text { tubule }\end{array}$ \\
\hline \multirow{2}{*}{ Cell size } & $6.37 \pm 0.60 \times$ & $15.45 \pm 0.60 \times$ & $14.70 \pm 1.18 \times$ & $16.67 \pm 0.14 \times$ \\
\hline & $4.89 \pm 0.38$ & $7.66 \pm 0.48$ & $8.38 \pm 0.74$ & $8.69 \pm 0.20$ \\
\hline \multirow{2}{*}{ Nucleus size } & $4.35 \pm 0.42 \times$ & $6.45 \pm 0.26 \times$ & $8.16 \pm 0.37 \times$ & $6.56 \pm 0.25 \times$ \\
\hline & $2.73 \pm 0.12$ & $3.16 \pm 0.32$ & $4.21 \pm 0.38$ & $4.45 \pm 0.33$ \\
\hline \multirow{2}{*}{ Mitochondrion size } & \multirow[b]{2}{*}{-} & $0.65 \pm 0.07 \times$ & $1.44 \pm 0.07 \times$ & $2.41 \pm 0.28 \times$ \\
\hline & & $0.10 \pm 0.01$ & $0.40 \pm 0.04$ & $0.65 \pm 0.11$ \\
\hline $\begin{array}{l}\text { Number of mitochond- } \\
\text { ria on a cell section }\end{array}$ & - & $22.40 \pm 2.23$ & $36.33 \pm 4.16$ & $28.25 \pm 1.28$ \\
\hline $\begin{array}{l}\text { Secretory } \\
\text { granules size }\end{array}$ & - & $\begin{array}{c}1.46 \pm 0.09 \times \\
0.80 \pm 0.17\end{array}$ & - & - \\
\hline $\begin{array}{l}\text { Number of granules } \\
\text { on a cell section }\end{array}$ & - & $13.0 \pm 3.02$ & - & - \\
\hline Endocytosis zone size & - & $3.53 \pm 0.24$ & $2.26 \pm 0.17$ & - \\
\hline Brush border size & - & $2.33 \pm 0.41$ & $1.68 \pm 0.12$ & - \\
\hline Microvilli size & - & $0.32 \pm 0.06$ & $0.29 \pm 0.07$ & - \\
\hline Cilia size & - & $0.20 \pm 0.01$ & $0.20 \pm 0.01$ & - \\
\hline
\end{tabular}

The type II epithelial cells were similar to the type I epithelial cells in general, but they were smaller in height (Table 4). The type II epithelial cells also had round-shaped nuclei located in the basal part of the cells. The heterochromatin was segmented, most of it located along the nuclear membrane, between the nuclear pores. The cytoplasm of these cells was less acinose, in comparison with that in the type I epithelial cells, and had a greater amount of larger mitochondria (Table 4). The membrane projections of the basal cell membrane were better develo- 
ped. A characteristic feature of the type II epithelial cells was the absence of secretory granules in the cytoplasm. Although the tubulo-vesicular network was present, the endocytosis zone was smaller in comparison with the type I epithelial cells (Table 4, Fig. 3h, 3i). The brush border was shorter; it was formed by both cilia, from ciliated epithelial cells, and microvilli (Table 4). In the ciliated type II epithelial cells, the cytoplasm had a greater amount of larger mitochondria in comparison with the main type II epithelial cells.

The epithelial cells in the distal tubule were high and very wide in the base (Table 4). The nuclei of most cells occupied the central part, sometimes were shifted to the basal part. Heterochromatin was both concentrated at the periphery of the nucleus between nuclear pores and diffused over the entire surface. In the cytoplasm of these cells, a large number of membrane projections were present. Large elongated electron-dense mitochondria, located strictly along the longitudinal axis throughout the cell, were observed (Fig. 3j). By the number of mitochondria, the epithelial cells of the distal tubule were superior to the type I epithelial cells and inferior to the type II epithelial cells of proximal tubules. The endocytosis zone was absent. In the apical part of the cells, the blade-shaped cytoplasmic processes, facing the lumen of the tubule, were observed. Some processes were rugose (Fig. 3k).

\section{Discussion}

Physiological endpoints of interest, i.e. antioxidant enzyme activities and monooxygenase activities, are well established biomarkers of chemical exposure (Whyte et al., 2000; Sayeed et al., 2003; Atli \& Canli, 2010; Sinha et al., 2014). Our results provide baseline data on superoxide dismutase, catalase, glutathione S-transferase, and ethoxyresorufin-O-deethylase activities in the grayling kidney. These endpoints are considered components of an "early-warning system" for fish health and thus can be used in further studies addressing the health status of the grayling population in the Unya River. In an attempt to conduct a discussion of the results from a comparative-evolutionary perspective, we used data obtained earlier for the grayling's close freshwater relative, the Northern pike Esox lucius (Lapirova et al., 2017). Northern pike is a member of the Esociformes, the sister order to the Salmoniformes within the Protacanthopterygii superorder, and it takes an ancestral position to Coregoninae, Thymallinae, and Salmoninae (Yasuike et al., 2010; Rondeau et al., 2014). Comparison of the studied physiological endpoints in the mesonephros of grayling and Northern pike showed some differences in the superoxide dismutase, glutathione S-transferase, and ethoxyresorufin-O-deethylase activities. The grayling had greater ethoxyresorufin-O-deethylase activity and smaller superoxide dismutase and glutathione S-transferase activities, compared with the Northern pike. At this stage of the ongoing study, we cannot distinguish between the evolutionary traits and the habitat conditions or dietary preferences in their capacity to contribute to the differences observed in these two species.

Histological analysis showed that the mesonephros organization of the grayling is similar to that of salmonid fishes inhabiting fresh waters (Balabanova, 2006; Katoh et al., 2008; Flerova \& Balabanova, 2013). In the interstitial tissue, erythrocytes, lymphocytes, plasma cells, as well as macrophages, neutrophils and eosinophils at different maturation stages were observed. Also, the cells with a radial vesicle array and chloride cells were identified; the latter were mostly found in the proximity to the nephron tubules. Agranulocytes, eosinophils, cells with a radial vesicle array, and chloride cells in grayling did not show any species-specific features in their ultrastructure, compared to those of the members of Salmoniformes and Esociformes studied earlier (Balabanova, 2006; Katoh et al., 2008; Flerova \& Balabanova, 2013; Flerova, 2017).

Yet, there were some differences found in the microanatomy of the mesonephros between the Protacanthopterygii members. In the mesonephros of grayling, the hematopoietic tissue was less developed in comparison with that of the Northern pike (Flerova, 2017; Lapirova et al., 2017). It seems that distinctive features of the anatomical organization of the mesonephros are associated with the processes of blood cell formation in the renal-spleen-type hematopoiesis, and, within the Protacanthopterygii superorder, are evident at the order level. A WBC differential analyses showed two types of granulocytes, neutrophils and eosinophils, in the mesonephros hematopoietic tissue in grayling. It was reported earlier (Kocabatmaz \& Ekingen, 1987) that in the mesonephros hematopoietic tissue of a salmonid member, rainbow trout Salmo gairdneri, only one type of granulocyte, the neutrophils, was found. However, in the mesonephros of the Northern pike, two types of granulocyte were observed (Flerova, 2017; Lapirova et al., 2017). The number of mature granulocytes may be considered a systematic characteristic of a species. In mesonephros of grayling, the percentage of each type of leukocyte varied within a short range. The greatest intra-specific variability was shown by lymphocytes and hemocytoblasts. A WBC differential is known to be a sensitive indicator of the physiological state of an organism and highly responsive to changes in an environment. A WBC differential has a wide reaction norm, which depends on the systematic position of the species as well. It was reported earlier (Keyster, 2009) that in vendace Coregonus albula from different parts of Lake Beloye, the percentage of neutrophils varied from $41 \%$ to $88 \%$, which made $74 \%$ on average. In grayling, a WBC differential, in general, was similar to that found in the Northern pike (Lapirova et al., 2017).

The differences between members of the Protacanthopterygii were observed not only in the granulocyte differential, but also in the quantity of granules on the sections of neutrophils and eosinophils as well as in the structure of specific granules in neutrophils. By the quantity of granules on the sections of neutrophils and eosinophils, the grayling had a resemblance to the Northern pike rather than to the more closely related rainbow trout and vendace (Flerova \& Balabanova, 2013). It was reported earlier (Flerova, 2017) that in the mesonephros of the Northern pike, the neutrophils had specific fibrillar granules, which could be conditionally divided into three types. In the mesonephros of grayling, the neutrophils had specific fibrillar granules with the ultrastructure similar to the type I and type II specific fibrillar granules of the Northern pike. The characteristic feature of the type III specific fibrillar granules was that the fibrils were located close to the central part of the cell. In neutrophils of rainbow trout and vendace, only one type of specific fibrillar granule was found, with a light central part and dark fibrillar edges (Flerova \& Balabanova, 2013). It was presumed earlier that the differences in the quantity of fibrils and their distribution between the granules of neutrophils are associated with a stage of the granule maturation rather than the species-specificity (Flerova \& Balabanova, 2013). The frequency of neutrophils having granules of a certain type on the sections of mesonephros and the quantity of granules on the sections of neutrophils and eosinophils are possibly characteristic to the cellular immunity functioning in the particular environmental conditions typical of the species habitats.

A lack of mesangial cells, small amount of podocytes on the sections of the renal corpuscle, and a thin basement membrane indicate the high glomerular filtration rate, which is characteristic of freshwater fishes (Ojeda et al., 2006). In grayling, the nephron does not possess a neck segment, which was observed earlier in the mesonephros of some fish (Ojeda et al., 2006; Flerova, 2017) and mammalian species (Ojeda \& Icardo, 1991). On sections of the proximal tubules, ciliated cells were rare, and large amounts of the tubulo-vesicular network in the zone of endocytosis of the type II epithelial cells were observed. On sections of the distal tubules, short blade-shaped cytoplasmic processes, with large numbers of invaginations of cytoplasmic membrane, were witnessed. It is well established that ciliated segments of nephron (neck segment and ciliated cells of proximal tubules) are involved in the processing the fluid. The cilia move the urine toward the proximal tubule, reducing the pressure in the urinary space and, consequently, increasing the glomerular filtration rate (Ojeda et al., 2006). Development of the tubular-vesicular network promotes the reabsorption rate in the proximal tubules (Flerova, 2017). Lumen enlargement due to short blade-shaped cytoplasmic processes probably lowers the resistance to urinary flow.

In the study of $\mathrm{Na}^{+} / \mathrm{K}^{+} / 2 \mathrm{Cl}^{-}$-cotransporter localization in the kidneys of an euryhaline salmonid, rainbow trout (Katoh et al., 2008), a lack of the neck segment and a small amount of cilia, which were mostly found in the tubule lumen, was recorded. Rainbow trout was lacking the $\mathrm{Na}^{+} / \mathrm{K}^{+} / 2 \mathrm{Cl}^{-}$-cotransporter, which mediates the electroneutral transport of $\mathrm{Na}^{+}, \mathrm{K}^{+}$, and $\mathrm{Cl}^{-}$across epithelial membranes, in the basolateral membrane of the proximal tubules. In the distal tubules, the apically 
located $\mathrm{Na}^{+} / \mathrm{K}^{+} / 2 \mathrm{Cl}^{-}$-cotransporters were observed, which it has been suggested play a role in $\mathrm{Na}^{+}, \mathrm{K}^{+}$, and $2 \mathrm{Cl}^{-}$absorption allowing the ions to be transported back into the body through basolateral-specific ion channels. Thus, the distal tubules could probably switch between secretion and absorption, depending on the osmoregulatory needs of the fish (Katoh et al., 2008). It is possible that the ultrastructural features observed in the grayling mesonephros in our study are the cytological markers of grayling being adapted to euryhalinity since it can occur in brackish waters and on small river rifts in the tidal backwater zones.

\section{Conclusion}

Our study provides new data on morpho-functional characteristics of the mesonephros in the grayling. The degree of the hematopoietic tissue development was determined. New data on the ultrastructure of leukocytes, cells with a radial vesicle array, chloride cells, and nephron segments were obtained. Common and distinctive features, as compared with members of Salmoniformes and Esociformes, in the mesonephros organization of grayling were reported. From the species protection standpoint, our study provides baseline data on a WBC differential in the mesonephros as well as superoxide dismutase, catalase, glutathione S-transferase, and ethoxyresorufin-O-deethylase activities, which can be used in further studies addressing the health status of grayling populations.

Acknowledgements. The study was funded by RFBR, research project 16-04-00650 "Morphofunctional organization of mesonephros in Salmoniformes". The authors are grateful to Vyacheslav S. Afanasyev and Igor M. Dyakov for their help in the field.

\section{References}

Anderson, B. G., \& Loewen, R. D. (1975). Renal morphology of freshwater trout. American Journal of Anatomy, 143(1), 93-113.

Atli, G., \& Canli, M. (2010). Response of antioxidant system of freshwater fish Oreochromis niloticus to acute and chronic metal $(\mathrm{Cd}, \mathrm{Cu}, \mathrm{Cr}, \mathrm{Zn}, \mathrm{Fe})$ exposures. Ecotoxicology and Environmental Safety, 73(8), 1884-1889.

Balabanova, L. V. (2006). Kletki s radialno raspolozhennymi vezikulami u ryb raznyh vidov [Cells with radiating vesicles in different fish species]. Cytology, 48(8), 636-640 (in Russian).

Björnsson, B. T., \& Bradley, T. M. (2007). Epilogue: Past successes, present misconceptions and future milestones in salmon smoltification research. Aquaculture, 273, 384-391.

Boeuf, G. (1993). Salmonid smolting: A pre-adaptation to the oceanic environment. In: Rankin, J. C., \& Jensen, F. B. (eds.). Fish Ecophysiology. Chapman and Hall Fish and Fisheries Series. Vol 9. Springer, Dordrecht.

Flerova, E. A. (2017). Osobennosti struktury mezonefrosa obyknovennoy shuki Esox lucius L. [Features of mesonephros structures common pike Esox lucius]. Problems of Fisheries, 18(4), 487-498 (in Russian).

Flerova, E. A., \& Balabanova, L. B. (2013). Ultrastructure of granulocytes of teleost fish (Salmoniformes, Cypriniformes, Perciformes). Journal of Evolutionary Biochemistry and Physiology, 49(2), 223-233.

Freyhof, J. (2011). Thymallus thymallus. The IUCN Red list of threatened species, 2011, e.T21875A9333742.

Katoh, F., Cozzi, R. R. F., Marshall, W. S., \& Goss, G. G. (2008). Distinct $\mathrm{Na}^{+} / \mathrm{K}^{+} /{ }_{2} \mathrm{Cl}^{-}$cotransporter localization in kidneys and gills of two euryhaline species, rainbow trout and killifish. Cell and Tissue Research, 334(2), 265-281.
Keyster, I. A. (2009). Morfologicheskiy sostav krovi ryapushki i eyo izmeneniya kak bioindikatsionnyie pokazateli usloviy obitaniya v Belom ozere (Vologodskaya oblast) [Morphological structure of blood of vendace and its changes as bioindicators of Beloe Lake (Vologda Region)]. Modern Problems of Science and Education, 3, 117-125 (in Russian).

Kocabatmaz, M., \& Ekingen, G. (1987). Comparative studies on leucocytes of some freshwater fish species. Selçuk Üniversitesi Veteriner Fakültesi Dergisi, 3(1), 71-81.

Langdon, J. S. (1985). Smoltification physiology in the culture of salmonids. In: Muir, J. F., \& Roberts, R. J. (Eds.). Recent Advances in Aquaculture. Springer, Boston. Pp. 79-118.

Lapirova, T. B., Flerova, E. A., Yurchenko, V. V., \& Morozov, A. A. (2017). Protective systems of immune-competent organs in the fish of various ecological and systematic groups. Journal of Ichthyology, 57(3), 458-466.

Mizuno, S, Misaka, N., \& Kasahara, N. (2001). Morphological changes in juxtaglomerular cells of the kidney during smoltification in masu salmon Oncorhynchus masou. Fisheries Science, 67(3), 538-540.

Morozov, A. A., \& Yurchenko, V. V. (2018). Seasonal changes in hepatic antioxidant enzyme activities of the perch Perca fluviatilis in the Upper Volga basin, Russia. Ichthyological Research, 65(2), 265-269.

Nykänen, M., Huusko, A., \& Mäki-Petäys, A. (2001). Seasonal changes in the habitat use and movements of adult European grayling in a large subarctic river. Journal of Fish Biology, 58(2), 506-519.

Ojeda, J. L., \& Icardo, J. M. (1991). A scanning electron microscope study of the neck segment of the rabbit nephron. Anatomy and Embryology, 184(6), 605-610.

Ojeda, J. L., Icardo, J. M., Wong, W. P., \& Ip, Y. K. (2006). Microanatomy and ultrastructure of the kidney of the African lungfish Protopterus dolloi. The Anatomical Record Part A: Discoveries in Molecular, Cellular, and Evolutionary Biology, 288A(6), 609-625.

Rondeau, E. B., Minkley, D. R., Leong, J. S., Messmer, A. M., Jantzen, J. R., von Schalburg, K. R., Lemon, C., Bird, N. H., \& Koop, B. F. (2014). The genome and linkage map of the northern pike (Esox lucius): Conserved synteny revealed between the salmonid sister group and the Neoteleostei. PloS One, 9(7), e102089.

Sayeed, I., Parvez, S., Pandey, S., Bin-Hafeez, B., Haque, R., \& Raisuddin, S. (2003). Oxidative stress biomarkers of exposure to deltamethrin in freshwater fish, Channa punctatus Bloch. Ecotoxicology and Environmental Safety, 56(2), 295-301.

Scott, A. (1985). Distribution, growth, and feeding of postemergent grayling Thymallus thymallus in an English River. Transactions of the American Fisheries Society, 114(4), 525-531.

Sinha, A. K., AbdElgawad, H., Giblen, T., Zinta, G., De Rop, M., Asard, H., Blust, R., \& De Boeck, G. (2014). Anti-oxidative defences are modulated differenttially in three freshwater teleosts in response to ammonia-induced oxidative stress. PLoS One, 9(4), e95319.

Talbot, C., Stagg, R. M., \& Eddy, F. B. (1992). Renal, respiratory and ionic regulation in Atlantic salmon (Salmo salar L.) kelts following transfer from fresh water to seawater. Journal of Comparative Physiology B, 162(4), 358-364.

Timakova, T. K., Flerova, E. A., \& Zabotkina, E. A. (2014). Metody svetovoy i elektronnoy mikroskopii $\mathrm{v}$ biologii $\mathrm{i}$ veterenarii [Methods of light and electronic microscopy for biology and veterinary science]. Yaroslavskaya GSHA, Yaroslavl (in Russian).

Yasuike, M., Jantzen, S., Cooper, G. A., Leder, E., Davidson, W. S., \& Koop, B. F. (2010). Grayling (Thymallinae) phylogeny within salmonids: Complete mitochondrial DNA sequences of Thymallus arcticus and Thymallus thymallus. Journal of Fish Biology, 76(2), 395-400.

Yurchenko, V. V., \& Morozov, A. A. (2018). Intra-annual variability of hepatic ethoxyresorufin-O-deethylase activity in freshwater bream Abramis brama. Biological Rhythm Research, 2018, in press. 